\title{
Kelimpahan dan Keanekaragaman Jenis Ikan di Perairan Ndalir Kabupaten Merauke, Papua
}

\author{
Abundance and Fish Diversity in Ndalir Waters of Merauke \\ Regency, Papua
}

\author{
Dandi Saleky $^{1 *}$, Efraim Weremba ${ }^{1}$, Marius A. Welikken ${ }^{1}$ \\ 1 Universitas Musamus Merauke
}

\section{Info Artikel:}

Diterima: 08/07/2021

Disetujui: $13 / 08 / 2021$

Dipublikasi: 01/10/2021

\section{Kata Kunci:}

Keragaman, Dominansi, Kelimpahan, Perairan

Ndalir

\section{Keywords:}

Diversity, Dominance, Abundance, Ndalir Waters

*Korespondensi: dandi@unmus.ac.id

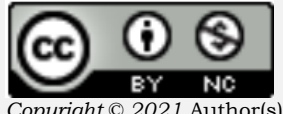

\begin{abstract}
Abstrak. Penelitian ini bertujuan menganalisis keanekaragaman jenis ikan yang tertangkap di Pesisir Ndalir Kabupaten Merauke. Penelitian ini dilakukan pada bulan Juli-Agustus 2020. Penentuan titik sampling pada lokasi penelitian menggunakan metode purposive random sampling dengan 2 stasiun pengamatan. Analisis data yang digunakan dalam penelitian ini adalah kelimpahan relatif $(\mathrm{Kr})$, indeks Shannon-Wienner $\left(\mathrm{H}^{\prime}\right)$, indeks keseragaman $(\mathrm{E})$, dan indeks dominasi (C). Total hasil tangkapan ikan selama waktu penelitian berjumlah 431 ekor, yang terbagi kedalam 12 spesies ikan. Stasiun dua memiliki jumlah tangkapan yang lebih banyak dibandingkan stasiun satu. Kelimpahan relatif tertinggi adalah ikan lidah (Cynoglossus abbreviates) (Stasiun I) dan ikan belanak (Mugil cephalus) (Stasiun II). Nilai indeks keanekaragaman jenis pada kedua stasiun pengamatan adalah dalam kategori sedang. Nilai indeks keseragaman dan dominansi memperlihatkan bahwa spesies pada kedua stasiun penelitian tersebar merata dengan tidak ada spesies yang mendominasi.
\end{abstract}

\begin{abstract}
This study aims to analyze the diversity of fish species caught on the Ndalir Coast of Merauke Regency. This research was conducted in Juli-August 2020. The determination of the sampling points at the research location used the purposive random sampling method with two observation stations. Analysis of the research data using relative abundance $(\mathrm{Kr})$, Shannon-Wienner index ( $\left.\mathrm{H}^{\prime}\right)$, uniformity index $(E)$, and dominance index $(C)$, The number of fish catches during the study time was 431 which were divided into 12 species of fish. Station two has a greater number of catches than station one. The highest relative abundance was tongue fish (Cynoglossus abbreviation) (Station I) and mullet (Mugil cephalus) (Station II). The diversity index value at the two observation stations is in the medium category. The uniformity and dominance index values show that the species at the two research stations are evenly distributed with no dominating species.
\end{abstract}

\section{PENDAHULUAN}

Sumberdaya ikan adalah salah satu sumberdaya hayati perairan yang penting (Mote, 2017; Sweking et al., 2018), sebagai salah satu sumber protein dalam kehidupan manusia (Cahya et al., 2016; Gebretsadik \& Gebretsadik Wana, 2016; Mardani, Arthur Mangalik, Yusurum Jagau, 2013). Ikan menjadi salah satu organisme yang menjadi kajian ekologi penting sehingga harus dijaga kelestariannya (Dailami et al., 2021; Fitrah, Dewiyanti, \& Rizwan, 2016). Berbagai kegiatan manusia banyak dilakukan pada daerah pesisir seperti alih fungsi lahan, kegiatan industri, kegiatan pertambangan minyak dan gas, transportasi dan pariwisata yang dapat 
menurunkan biodiversitas biota pesisir termasuk komposisi jenis ikan (Amanah, 2004; Tegar \& Saut Gurning, 2018).

Identifikasi dan inventarisasi jenis ikan merupakan langkah awal dalam pengelolaan dan pelestarian keanekaragaman ikan (Lasena \& Irdja, 2011; Saleky \& Dailami, 2021). Identifikasi sangat penting dilakukan karena keberhasilan pengelolaan sumberdaya daya dan penelitian penelitian yang dilakukan dikemudian hari sangat bergantung dari hasil identifikasi yang benar dari suatu spesies (Kurniawan et al., 2019). Identifikasi jenis ikan juga sangat penting dilakukan karena nama lokal sering tidak terdokumentasi dengan baik (Samitra, 2019).

Keanekaragaman jenis ikan merupakan sumberdaya perairan yang dapat digali terutama jenis ikan yang memiliki nilai ekonomi yang bermanfaat bagi kehidupan manusia (Mardani, Arthur Mangalik, Yusurum Jagau, 2013; Saleky et al., 2021). Komposisi dan keanekaragaman jenis ikan sangat dipengaruhi berbagai faktor seperti faktor makanan (Taunay \& Redjeki, 2013), pemangsaan (Baskoro, 2008), degradasi habitat (Negi \& Mamgain, 2013), kondisi fisik-kimia perairan (Cahya et al., 2016; GrapciKotori et al., 2019; Prayitno \& Rukayah, 2019), kompleksitas habitat yang tersedia (Hukom \& Bay, 2010; Simanjuntak, 2012), perubahan genetik akibat eksploitasi berlebih (Dailami et al., 2021; Gebretsadik \& Gebretsadik Wana, 2016) serta tekanan antropogenik (Eddy et al., 2012). Introduksi spesies asing yang bersifat invasif (SAI) juga menjadi salah satu ancaman utama terhadap keanekaragaman hayati dan ekosistem alam (Baskoro, 2008; Gunawan \& Jumadi, 2016).

Wilayah pesisir Merauke memiliki potensi sumberdaya hayati laut maupun payau yang potensial dan bernilai ekonomis (Saleky \& Merly, 2021; Sunarni \& Maturbongs, 2016). Diperlukan suatu upaya untuk mendukung peningkatan nilai ekonomi sekaligus menjaga dan melindungi kelestariannya. Salah satu upaya yang dapat dilakukan adalah dengan mengidentifikasi jenis ikan (Fitrah et al., 2016) termasuk ikan yang tertangkap di perairan pesisir Ndalir Kabupaten Merauke.

\section{METODE PENELITIAN}

Penelitian ini dilaksanakan pada bulan Juli - Agustus 2020 di perairan Pesisir Ndalir Kabupaten Merauke (Gambar 1). Identifikasi jenis dan analisis data dilakukan di Laboratorium Manajemen Sumberdaya Perairan Fakultas Pertanian, Universitas Musamus Merauke. Objek dalam penelitian ini adalah ikan yang tertangkap di Perairan Pesisir Ndalir Kabupaten Merauke. Pengambilan sampel dilakukan pada 2 stasiun pengamatan di Perairan Pesisir Ndalir. Pengambilan contoh ikan dilakukan dengan menggunakan alat tangkap yaitu pukat pantai. Metode identifikasi ikan dengan melihat ciri morfologi untuk mempermudah klasifikasi (Lasena 
\& Irdja, 2011) dengan menggunakan buku identifikasi Marine Fishes of South - East Asia (Allen, 1999), Ken Schultz's Field Guide to Saltwater Fish (Schultz, 2003) dan FishBase (FishBase: A Global Information System on Fishes).

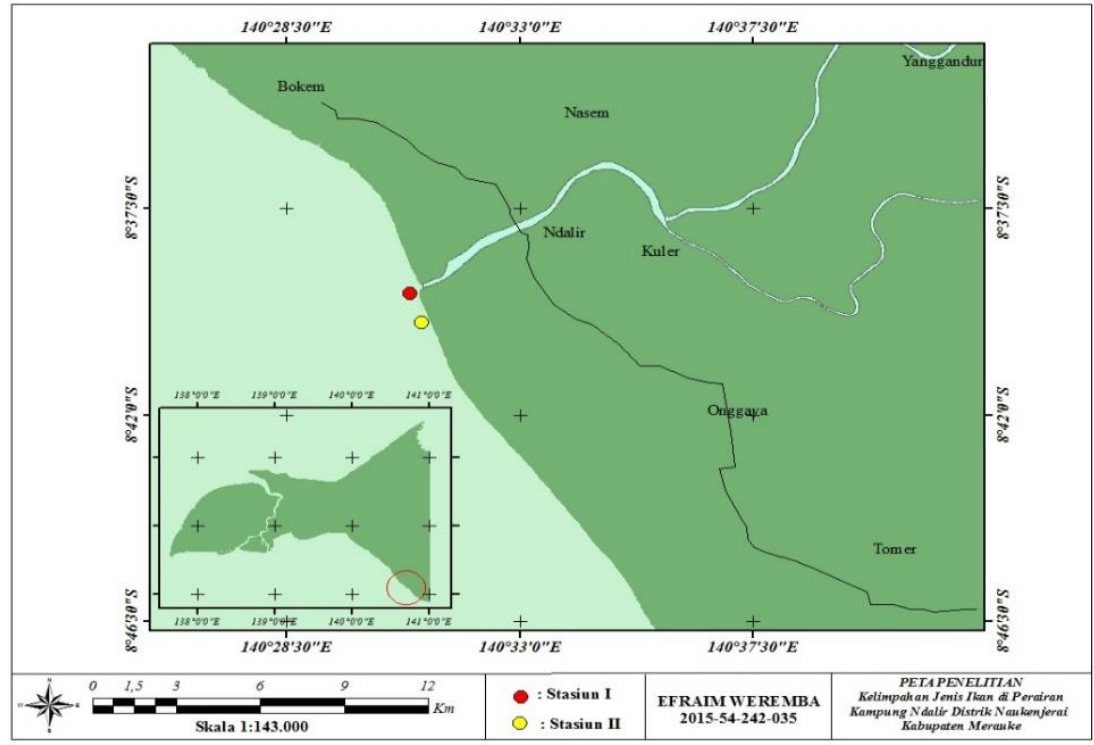

Gambar 1. Peta lokasi penelitian kelimpahan jenis ikan di Perairan Ndalir Kabupaten Merauke, Papua

Sampel ikan yang diperoleh kemudian didokumentasikan, dilanjutkan dengan identifikasi jenis dan menuliskan deskripsi jenis sampel yang ditangkap. Klasifikasi dilakukan sampel sampai spesies beserta nama daerahnya. Data yang diperoleh dari penelitian ini dianalisis dengan menggunakan analisis kuantitatif yaitu data yang dikelola dari perilaku yang diamati kemudian ditabulasi dan digambarkan lewat grafik (Pondaag et al., 2018). Analisis data yang digunakan adalah Kelimpahan Relatif, Indeks keanekaragaman, Indeks Keseragaman dan Indeks Dominansi.

\section{HASIL DAN PEMBAHASAN}

\section{Komposisi Spesies}

Selama penelitian, terkoleksi 431 ekor ikan yang terdiri atas 12 spesies (Tabel 1). Seluruh spesies yang dikoleksi ditemukan pada kedua stasiun penelitian. Jenis ikan yang tertangkap dalam penelitian ini diantaranya Eleuteronema tetradactylum, Hexanematichthys sagor, Tenualosa ilisha dan jenis lainnya. Spesies yang paling banyak terkoleksi pada stasiun satu adalah ikan duri Hexanematichthys sagor sebanyak 52 individu, sedangkan spesies yang paling banyak terkoleksi di stasiun 2 adalah ikan belanak sebanyak 78 individu. Spesies ikan yang tertangkap selama penelitian ini merupakan ikan spesies yang umumnya ditemukan di Perairan Merauke (Sunarni dan Maturbongs, 2016). 
NEKTON, Vol 1 No 2 Oktober 2021: hal 84 - 93

Tabel 1. Klasifikasi spesies ikan yang ditemukan di Perairan Ndalir Kabupaten Merauke

\begin{tabular}{ccccc}
\hline No & Family & Genus & Spesies & Nama lokal \\
\hline 1 & Polynemidae & Eleuteronema & $\begin{array}{c}\text { Polydactylus } \\
\text { plebejus } \\
\text { Hexanematichthys }\end{array}$ & Kuro \\
2 & Ariidae & Hexanematichthys & Duri \\
3 & Clupeidae & Tenualosa & Tenualosa ilisha & Tembang \\
4 & Mugilidae & Valamugil & Mugil cephalus & Belanak \\
5 & Plotosidae & Plotosus & Plotosus canius & Sembilan \\
6 & Latidae & Lates & Lates carcarifer & Kakap Putih \\
7 & Sciaenidae & Nibea & Nibea saldado & Gulamah \\
8 & Tetraodontidae & Tetraodon & Marlyna & Buntal \\
9 & Cynoglossidae & Cynoglossus & Cynoglossus & abbreviatus \\
10 & Dasyatidae & Dasyatis & Dasyatis pastinaca & Pari \\
11 & Hemiramphidae & Strongylura & Strongylura & Julung \\
& & Ptrongylura & Eleuteronema & Bandang \\
12 & Polynemidae & Eleuteronema & tetradactylum & \\
\hline
\end{tabular}

Selama penelitian, stasiun 2 memiliki jumlah ikan terbanyak dengan jumlah tangkapan 253 ekor (58.7\%) dari total tangkapan, sedangkan hasil tangkapan pada stasiun 1 sebanyak 178 ekor (41.3\%) dari total tangkapan (Gambar 2).

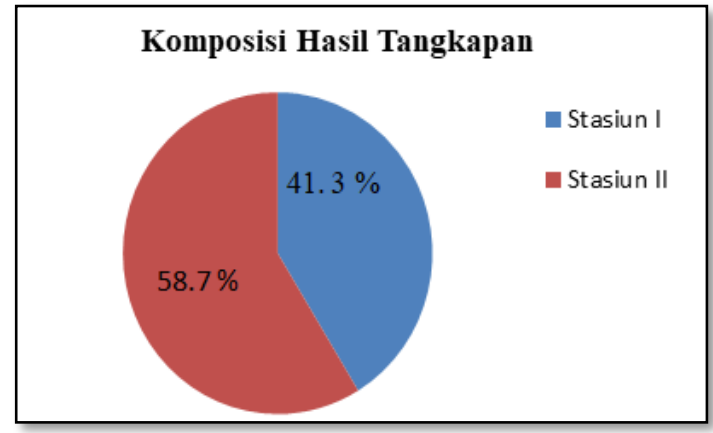

Gambar 2. Persentase jumlah pada kedua stasiun pengamatan

Berdasarkan hasil pengamatan pengamatan per bulan, hasil tangkapan pada bulan Juli memiliki jumlah tangkapan terbanyak yaitu 259 ekor (60.1\%) sedangkan pada bulan Agustus sebanyak 172 ekor (39.9\%) dari total hasil tangkapan. Musim timur yang berlangsung di Pesisir Merauke pada bulan Juni mengakibatkan tangkapan pada bulan tersebut sangat melimpah. Selain faktor tersebut, sedikitnya jumlah hasil tangkapan pada bulan Agustus dipengaruhi oleh pada bulan Agustus merupakan peralihan musim hujan ke musim kemarau. 


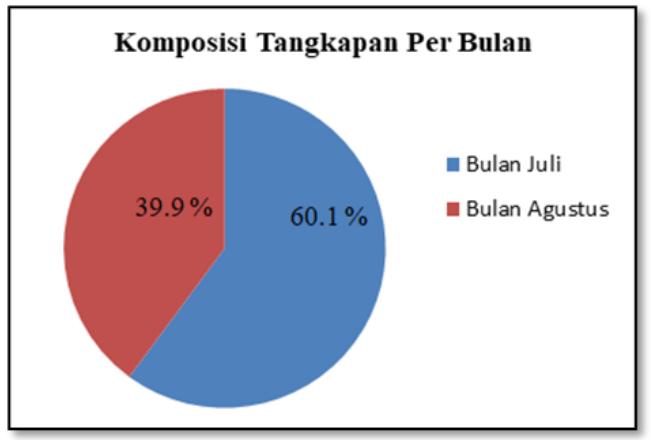

Gambar 3.Komposisi hasil tangkapan per bulan

Berbagai jenis ikan yang tertangkap adalah jenis ikan yang umumnya hidup melimpah pada daerah muara, pantai berlumpur maupun sungai. Kesamaan sebaran dan komposisi spesies ikan yang dikoleksi menunjukkan ke dua stasiun penelitian tersebut menyediakan relung (habitat dan makanan) yang sama (Negi \& Mamgain, 2013; Simanjuntak, 2012). Komposisi spesies ikan dalam suatu habitat sangat dipengaruhi oleh berbagai parameter yang kompleks baik faktor fisika, kimia dan biologi (Ulfah et al., 2019). Polutan kimiawi, limbah domestik dan sedimentasi turut berpengaruh dalam distribusi maupun komposisi spesies ikan (Edrus \& Abrar, 2017).

Faktor suhu dan gradient lingkungan termasuk didalammnya ukuran muara dan konektivitas hidrologi sangat berpengaruhi terhadap distribusi ikan antar sungai, muara dan laut (Henriques et al., 2017). Sehingga muara yang luas di wilayah yang dingin dengan konektivitas hidrologi yang tinggi memiliki proporsi ikan laut yang tinggi dibandingkan dengan muara yang lebih sempit.

\section{Kelimpahan relatif}

Kepadatan relatif adalah perbandingan antara kelimpahan individu tiap jenis dengan keseluruhan individu yang tertangkap dalam suatu komunitas (Insafitri, 2010). Diketahuinya nilai kepadatan relatif maka akan didapat juga nilai indeks dominansi. Berdasarkan kriteria kelimpahan relatif maka ikan lidah (Cynoglossus abbreviates) (Stasiun I) dan ikan belanak Mugil cephalus (Stasiun II), sedangkan jenis lainnya memiliki kelimpahan relatif yang jarang.

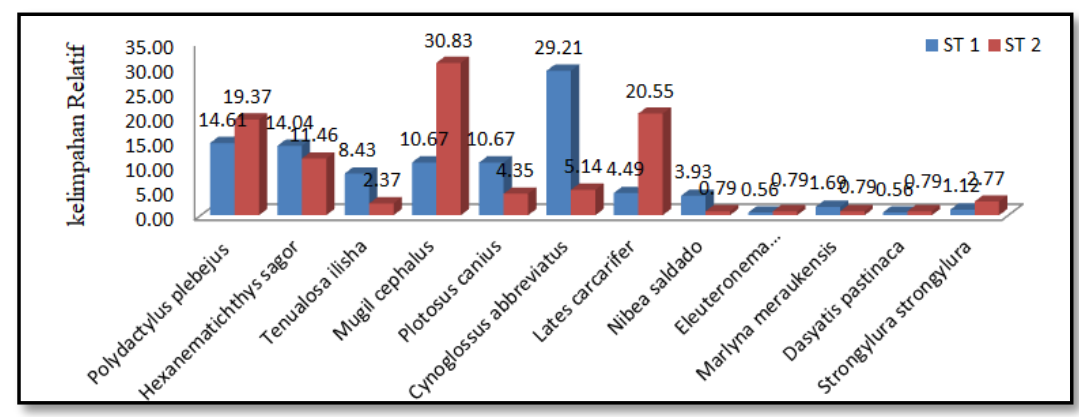

Gambar 4. Nilai kelimpahan relatif $(\mathrm{Kr})$ setiap spesies dari perairan Ndalir 
Faktor yang menyebabkan adanya kelimpahan spesies seperti preferensi habitat sehingga spesies tertentu dapat ditemukan di satu lokasi namun tidak dijumpai di lokasi lain (Simanjuntak, 2012). Selain itu juga kelimpahan spesies dipengaruhi oleh substrat, salinitas, kemampuan bertahan terhadap arus dan ombak, faktor ketersediaan sumber makanan, serta faktor perlindungan diri dari keadaan disekitar (Aryani et al., 2020; Ravichandran et al., 2001; Syahrial et al., 2020).

\section{Indeks Keanekaragaman, Keseragaman dan Dominansi}

Keanekaragaman hayati sangat penting untuk keberlanjutan masa depan sumber daya alam laut termasuk perikanan komersial (Rizwan et al., 2017). Nilai keanekaragaman dan keseragaman dapat menunjukkan keseimbangan dalam suatu pembagian jumlah individu tiap jenis (Latuconsina et al., 2012; Odum, 1971). Nilai Indeks keanekaragaman jenis (Tabel 2) di kedua lokasi memiliki nilai 1.264 (stasiun 1) dan 1.422 (Stasiun 2). Hasil tersebut menunjukkan keanekaragaman pada kedua stasiun memiliki tingkat keanekaragaman yang sedang. Hasil penelitian Sunarni dan Maturbongs, (2016) di Pantai Payum merauke menemukan keanekaragaman ikan yang tinggi, sedangkan penelitian Buhdy et al., (2018) menemukan keanekaragaman ikan yang sedang. Keanekaragaman dipengaruhi oleh jumlah jenis yang ditemukan dilokasi penelitian (Odum, 1971).

Tabel 2. Nilai Indeks Keanekaragaman (H'), Keseragaman (E) \& Dominansi (C)

\begin{tabular}{cccc}
\hline Stasiun & Keanekaragaman $\left(\mathrm{H}^{\prime}\right)$ & Keseragaman $(\mathrm{E})$ & Dominansi $(\mathrm{c})$ \\
\hline 1 & 1.264 & 0.836 & 0.39 \\
2 & 1.422 & 0.829 & 0.44 \\
\hline
\end{tabular}

Hasil analisis Indeks Keseragaman memiliki nilai 0.836 (stasiun 1) dan 0.829 (stasiun 2) menujukan tingkat populasi ikan pada kedua lokasi penelitian seragam. dan Indeks Dominansi (Tabel 2) menunjukkan pada kedua lokasi penelitian memiliki sebaran spesies ikan yang merata dengan tidak spesies yang mendominasi. Kondisi tersebut juga dipengaruhi oleh kondisi lingkungan yang menentukan distribudi ikan pada lokasi tersebut (Karnan et al., 2019). Selain faktor lingkungan, tidak adanya predator dari berbagai jenis ikan yang berada pada kedua lokasi tersebut menyebabkan spesies ikan dapat menyebar merata (Sunarni dan Maturbongs, 2016).

\section{KESIMPULAN}

Total 12 spesies ikan ditemukan di Perairan Pesisir ndalir yaitu Ikan kuro (Polydactylus plebejus), Ikan Duri (Hexanematichthys sagor), Ikan Tembang (Tenualosa ilisha), Ikan Belanak (Mugil cephalus), Ikan Sembilan 
(Plotosus canius), Ikan Kakap Putih (Lates calcarifer), Ikan Gulamah (Nibea saldado), Ikan buntal (Marlyna meraukensis), Ikan Lidah (Cynoglossus abbreviates), Ikan Pari (Dasyatis pastinaca), Ikan Julung-julung (Strongylura strongylura) dan Ikan bandang (Eleuteronema tetradactylum). Kelimpahan relatif tertinggi adalah jenis Ikan Belanak (Mugil cephalus) dan Ikan Lidah (Cynoglossus abbreviates). Hasil analisis ekologi pada kedua stasiun ditemukan kedua stasiun penelitian tersebut memiliki keankeragaman jenis yang sedang dengan komposisi seragam dan tidak terdapat spesies yang mendominansi.

\section{DAFTAR PUSTAKA}

Allen, G. (1999). Marine Fishes of South-East Asia. Periplus Edition (HK) Ltd. Amanah, S. (2004). Perencanaan Strategis Pengelolaan Sumberdaya Pesisir Terpadu di Kelurahan Pulau Panggang Kecamatan Seribu Utara, Kabupaten Kepulauan Seribu Provinsi DKI Jakarta. Buletin Ekonomi Perikanan, 5(2), 1-16.

Aryani, N., Suharman, I., Azrita, A., Syandri, H., \& Mardiah, A. (2020). Diversity and distribution of fish fauna of upstream and downstream areas at koto panjang reservoir, Riau province, Indonesia. F1000Research, $8, \quad 1-17$. https://doi.org/10.12688/f1000research.19679.1

Baskoro, K. (2008). Ekologi Pemangsaan Ikan Oskar dan Potensi Dampak Introduksinya. 1, 1-10.

Buhdy, R. S., Mote, N., \& Melmambessy, E. H. (2018). Keanekaragaman Jenis Ikan Di Sungai Digoel Distrik Edera Kabupaten Mappi. Musamus Fisheries and Marine Journal, 1(1), 1-14. https: / / doi.org/ 10.35724/mfmj.v1i1.1503

Cahya, C. N., Setyohadi, D., \& Surinati, D. (2016). Pengaruh Parameter Oseanografi terhadap Distribusi Ikan. Oseana, 41(4), 1-14.

Dailami, M., Rahmawati, A., Saleky, D., \& Toha, A. H. A. (2021). DNA barcoding of tilapia fish from Merauke , Papua and Malang , East JavaIndonesia. 14(2), 849-858.

Eddy, S., Gaffar, A. K., \& Oktaviani, E. (2012). Inventarisasi dan Identifikasi Jenis-Jenis Ikan di Perairan Sungai Musi Kota Palembang. Sainmatika: Jurnal Ilmiah Matematika Dan Ilmu Pengetahuan Alam, 9(2), 20-27.

Edrus, I. N., \& Abrar, M. A. (2017). Diversity of Reef Fish Fungsional Groups in Terms of Coral Reef Resiliences. Indonesian Fisheries Research Journal, 22(2), 109. https://doi.org/10.15578/ifrj.22.2.2016.109-122

FishBase : A Global Information System on Fishes. (n.d.). Retrieved June 19, 2020, from https://www.fishbase.de/home.htm

Fitrah, S. S., Dewiyanti, I., \& Rizwan, T. (2016). IDENTIFIKASI JENIS IKAN DI PERAIRAN LAGUNA GAMPOENG PULOT KECAMATAN LEUPUNG ACEH BESAR. Jurnal Ilmiah Mahasiswa Kelautan Dan Perikanan Unsyiah, 1(2), 66-81.

Fitrah, S. S., Dewiyanti, I., Rizwan, T., Syiah, U., \& Darussalam, K. (2016). Identifikasi jenis ikan di perairan laguna gampoeng pulot kecamatan 
leupung aceh besar. Prosiding SNATIF, 1(April), 66-81.

Gebretsadik, T., \& Gebretsadik Wana, T. (2016). A Review on the Causes for the Loss of Major Fishes and Prospects for Future Research in Ethiopia Survey on honeybee pests and predators in Sidama and Gedeo zones of Southern Ethiopia with emphasis on control practices View project $A$ Review on the Causes . July. www.iiste.org

Grapci-Kotori, L., Ibrahimi, B., Bilalli, A., Ibrahimi, H., \& Musliu, M. (2019). The Composition, Distribution and Abundance of Fish Species According to the Effects of Water Physicochemical Parameters in the Livoq Lake, Kosovo. Journal of Ecological Engineering, 20(5), 235-241. https:/ / doi.org/10.12911/22998993/10535

Gunawan, E. H., \& Jumadi. (2016). Keanekaragaman Jenis dan Sebaran Ikan yang Dilindungi, Dilarang Dan Invasif Di Kawasan Konservasi Rawadanau Banten. Jurnal Perikanan Dan Kelautan, 6 No.1(Juni), 6773.

https://www.researchgate.net/profile/Eko_Gunawan2/publication/3 38006973_Jurnal_Eko_Hendri/links/5df9f5b3299bf10bc3636c5c/Jur nal-Eko-Hendri.pdf?origin=publication_detail

Henriques, S., Guilhaumon, F., Villéger, S., Amoroso, S., França, S., Pasquaud, S., Cabral, H. N., \& Vasconcelos, R. P. (2017). Biogeographical region and environmental conditions drive functional traits of estuarine fish assemblages worldwide. Fish and Fisheries, 18(4), 752-771. https:/ / doi.org/10.1111/faf.12203

Hukom, F. D., \& Bay, K. (2010). KEANEKARAGAMAN DAN KELIMPAHAN SUMBERDAYA IKAN DI TELUK KLABAT , PERAIRAN BANGKA BELITUNG [ Diversity and abundance of fishes resources in Klabat Bay , Bangka Belitung Seas ]. 10(1), 11-23.

Insafitri. (2010). Keanekaragaman, Keseragaman, dan Dominansi Bivalvia di Area Buangan Lumpur Lapindo Muara Sungai Porong. Jurnal Kelautan. Universitas Trunojoyo, 3(1), 54-59.

Karnan, K., Japa, L., \& Raksun, A. (2019). Struktur Komunitas Sumberdaya Ikan Padang Lamun Di Teluk Ekaslombok Timur. Jurnal Biologi Tropis, 15(1), 5-14. https://doi.org/10.29303/jbt.v15i1.1067

Kurniawan, Asmarita, \& Supratman, O. (2019). IDENTIFIKASI JENIS IKAN (PENAMAAN LOKAL, NASIONAL DAN ILMIAH) HASIL TANGKAPAN UTAMA (HTU) NELAYAN DAN KLASIFIKASI ALAT PENANGKAP IKAN DI PULAU BANGKA PROVINSI KEPULAUAN BANGKA BELITUNG. Akuatik Jurnal Sumberdaya Perairan, 13(1), 42-51.

Lasena, A., \& Irdja, A. M. (2011). TERHADAP PERTUMBUHAN DAN KELANGSUNGAN HIDUP BENIH IKAN NILA (Oreochromis niloticus ). Amrizal , et Al., 2011, 65-76.

Latuconsina, H., Nessa, M., \& Ambo-Rappe, R. (2012). Komposisi Spesies Dan Struktur Komunitas Ikan Padang Lamun Di Perairan Tanjung Tiram - Teluk Ambon Dalam. 4(1), 35-46.

Mardani, Arthur Mangalik, Yusurum Jagau, J. H. (2013). Inventarisasi Jenis Ikan Yang Tertangkap Di Beberapa Perairan Danau Di Wilayah Kecamatan Kamipang Kabupaten Katingan Kalimantan Tengah. EnviroScienteae, 9, 85-99.

Mote, N. (2017). Biodiversitas Iktiofauna Di Muara Sungai Kumbe 
Kabupaten Merauke. Al-Kauniyah: Jurnal Biologi, 10(1), 26-34. https://doi.org/10.15408/kauniyah.v10i1.4863

Negi, R. K., \& Mamgain, S. (2013). Species diversity, abundance and distribution of fish community and conservation status of tons river of Uttarakhand State, India. Journal of Fisheries and Aquatic Science, 8(5), 617-626. https://doi.org/10.3923/jfas.2013.617.626

Odum, E. P. (1971). Dasar-Dasar Ekologi. Gajah Mada University Press.

Pondaag, M. F., Sompie, M. S., \& Budiman, J. (2018). Komposisi hasil tangkapan jaring insang dasar dan cara tertangkapnya ikan di Perairan Malalayang (Composition catches of bottom gillnet and how to catch fish in Malalayang Waters). Jurnal Ilmu Dan Teknologi Perikanan Tangkap, 3(2), 62-67. https://doi.org/10.35800/jitpt.3.2.2018.21427

Prayitno, J., \& Rukayah, S. (2019). Distribusi Altitudinal Ikan di Sungai Banjaran. Seminar Nasional Sains \& Entrepreneurship, 1(1), 1-16.

Ravichandran, S., Soundarapandian, P., \& Kannupandi, T. (2001). Zonation anddistribution of crabs in Pichavaram mangrove swamp, southeast coast of India. Indian Journal Fish, 48(2), 221-226.

Rizwan, T., Nasution, T. K., Dewiyanti, I., Elrahimi, S. A., \& Putra, D. F. (2017). Fish diversity in the east coastal waters area of Aceh Besar District, Indonesia. AACL Bioflux, 10(5), 1180-1185.

Saleky, D., \& Dailami, M. (2021). Konservasi Genetik Ikan Kakap Putih (Lates calcarifer, Bloch, 1790) Melalui Pendekatan DNA Barcoding dan Analisis Filogenetik di Sungai Kumbe Merauke Papua. Jurnal Kelautan Tropis, 24(2), 141-150. https://doi.org/10.14710/jkt.v24i2.10760

Saleky, D., \& Merly, S. L. (2021). Pendekatan DNA Barcoding untuk Identifikasi Cassidula angulifera (Petit, 1841) (Moluska: Gastropoda). Jurnal Sumberdaya Akuatik Indopasifik, 5(1), 55-64.

Saleky, D., Sianturi, R., Dailami, M., \& Kusumah, A. B. (2021). Kajian Molekuler Ikan Oreochromis spp. dari Perairan Daratan MeraukePapua, Berdasarkan DNA Mitokondria Fragmen Gen Sitokrom Oksidase Subunit I. Jurnal Perikanan, 23(1), 37-43. https://doi.org/10.22146/jfs.61026

Samitra, D. (2019). IDENTIFIKASI JENIS-JENIS IKAN DI SUNGAI KELINGI KOTA LUBUKLINGGAU. February.

Schultz, K. (2003). Ken Schultz's Field Guide to Saltwater Fish. John Wiley \& Sons.

Simanjuntak, C. P. H. (2012). Keragaman dan Distribusi Spasio-Temporal Iktiofauna Sungai Asahan Bagian Hulu dan Anak Sungainya. Prosiding Seminar Nasional Ikan VII, 43-60.

Sunarni dan Maturbongs. (2016). Sebaran Dan Struktur Komunitas Ikan Di Daerah Estuary Pesisir Pantai Kota Merauke Kaitannya Dengan Fenomena Pasang Surut. Dipa Unmus, September 2017.

Sweking, S., Najamuddin, A., \& Firlianty, F. (2018). Jenis-jenis Ikan Yang Tertangkap Dengan Jaring Insang Tetap (Set Gill Net), CPUE dan Panjang Baku Ikan di Danau Burung, dan Danau Hanjalutung di Kelurahan Petuk Ketimpun, Provinsi Kalimantan Tengah. Agrikan: Jurnal Agribisnis Perikanan, $11(2), \quad 51$. https://doi.org/10.29239/j.agrikan.11.2.51-58

Syahrial, Saleky, D., Samad, A. P. A., \& Tasabaramo, I. A. (2020). Ekologi 
Perairan Pulau Tunda Serang Banten:Keadaan Umum Hutan Mangrove. Jurnal Sumberdaya Akuatik Indopasifik, 4(1), 53-67. https:/ / journalfpikunipa.ac.id/index.php/JSAI/article/view/103/57

Taunay, P. N., \& Redjeki, S. (2013). Studi Komposisi Isi Lambung Dan Kondisi Morfometri Untuk Mengetahui Kebiasaan Makan Ikan Manyung ( Arius thalassinus ) Yang Diperoleh Di Wilayah Semarang. Jurnal of Marine Research, 2(1), 87-95.

Tegar, D., \& Saut Gurning, R. O. (2018). Development of Marine and Coastal Tourism Based on Blue Economy. International Journal of Marine Engineering Innovation and Research, 2(2). https://doi.org/ 10.12962/j25481479.v2i2.3650

Ulfah, M., Fajri, S. N., Nasir, M., Hamsah, K., \& Purnawan, S. (2019). Diversity, evenness and dominance index reef fish in Krueng Raya Water, Aceh Besar. IOP Conference Series: Earth and Environmental Science, 348(1). https://doi.org/10.1088/1755-1315/348/1/012074 